\title{
Upaya Peningkatan Higher Order Thinking Skills (HOTS) Siswa Melalui Penerapan Model Inquiri di SMA Negeri 9 Tanjung Jabung Timur
}

\author{
Mohamad Muspawi, Suratno, Ridwan \\ Universitas Jambi \\ Correspondence email: muspawi01@gmail, suratnounja@gmail.com,ridwanawang73@gmail.com
}

\begin{abstract}
This study aims to determine the improvement of Higher Order Thinking Skills (HOTS) in Economics lessons through the Inquiry model in class $X$ students. IPS. 1 Tanjung Jabung Timur 9 High School. This research was conducted in Tanjung Jabung Timur 9 High School in the academic year 2018/2019. This research is classroom action research with research procedures covering the stages of planning, implementation, observation, and reflection. The subjects of this study were all students of class $X$. IPS.1 Tanjung Nabung Timur High School 99 which consisted of 36 students consisting of 16 male students and 20 female students. The object of this research is the application of the Inquiry model to improve Higher Order Thinking Skills (HOTS). Data collection techniques used were observation, interview, documentation, journal and test assessment. Analysis of data obtained by calculating the percentage of graduation of students in high-level thinking skills. The results of the study showed that there was an increase in Higher Order Thinking Skills in Economics in class X students. IPS. 1 SMA N 9 Tanjung Jabung Timur. It can be seen that the average increase and graduation from cycle to cycle. In the first cycle the percentage of student graduation was $36.11 \%$ and HOTS was 13, and in the second cycle it increased by $41.67 \%$ with HOTS as many as 15.
\end{abstract}

Keyword: HOTS, Inquiry Model.

\section{PENDAHULUAN}

Pendidikan merupakan kebutuhan pokok yang sangat penting bagi manusia yang tidak dapat dihindari, baik pendidikan formal maupun informal. Mengingat pendidikan dijadikan sebagai salah satu tolak ukur tingkat kesejahteraan manusia. Berkualitas tidaknya kesejahteraan seseorang dipengaruhi oleh sejauh mana kualitas pendidikan yang didapatkannya di sekolah.

Kualitas pendidikan tersebut tentu saja tidak terlepas dari proses belajar mengajar siswa di sekolah. Proses belajar mengajar di kelas, guru sebagai ujung tombak dalam pencapaian tujuan pembelajaran harus memiliki metode belajar mengajar yang tepat agar siswa dapat belajar secara efektif dan efisien pada semua mata pelajaran termasuk proses pelaksanaan belajar mengajar mata pelajaran ekonomi.

Ekonomi merupakan mata pelajaran yang menarik karena sangat dekat dengan kehidupan sehari-hari. Semua aspek dalam kehidupan manusia hampir berhubungan dengan ilmu ekonomi. Mata pelajaran Ekonomi selalu berkembang dan sangat luas yang dapat memungkinkan siswa mengalami permasalahan tersendiri dalam memahami pelajaran tersebut. Mata pelajaran ekonomi merupakan materi yang berkembang dan dekat pada kehidupan dunia nyata masyarakat, sehingga membutuhkan pendalaman khusus. Perolehan informasi yang kurang maksimal dapat mempengaruhi belajar siswa. Penggunaan metode pembelajaran yang tidak tepat, juga dapat menghambat proses belajar mengajar di kelas.

Kurikulum 2013 merupakan kurikulum yang dikembangkan dengan pendekatan pembelajaran saintifik dalam rangka menyiapkan siswa untuk memiliki keterampilan berpikir kritis. Ada lima tahap utama dikembangkan dalam pembelajaran yaitu mengamati, menanya, mengeksplorasi/ mencoba, mengasosiasi/ menyimpulkan, dan mengkomunikasikan. Melalui kelima tahap pembelajaran tersebut siswa dituntut memiliki empat kompetensi sekaligus yaitu sikap relegius, sikap sosial, kompetensi pengetahuan dan kompetensi keterampilan. Keterampilan berpikir kritis merupakan tujuan yang harus dicapai oleh peserta didik dari kegiatan pembelajaran.

Kegiatan pembelajaran ditandai dengan kegiatan yang berpusat pada siswa (center learning), guru bertindak sebagai fasilitator. Untuk mengelola kegiatan pembelajaran, pemerintah memberikan beberapa alternatif model pembelajaran yang dapat melatih daya kritis peserta didik terhadap permasalahan, berfikir logis, kreatif, cermat, objektif dan dapat meningkatkan ketajaman penalaran peserta didik.

Permasalahan yang sering terjadi pada proses belajar mengajar mata pelajaran ekonomi di SMAN 9 Tanjung Jabung Timur yaitu guru masih menggunakan metode mengajar secara konvensional, pernyataan tersebut dari guru mata pelajaran ekonomi yaitu masih menggunakan metode lama yaitu ceramah. Bahkan pernyataan dari kepala sekolah, terkadang guru mengajar di kelas tidak membawa Rencana Pelaksanaan Pembelajaran (RPP) karena terbiasa dengan cara-cara lama dalam mengajar. Sementara di kurikulum 2013 dituntut siswa yang lebih aktif dibanding guru. Hamalik (2001:220) mengatakan bahwa pembelajaran inkuiri adalah strategi pembelajaran yang berpusat pada siswa, biasanya siswa diarahkan untuk belajar kelompok, siswa diarahkan dan dipusatkan pada satu pokok persoalan, atau siswa diarahkan untuk mencari jawaban-jawaban dan pertanyaan yang sudah ditetapkan.

Berdasarkan hasil observasi awal yang dilakukan oleh peneliti, siswa kurang dapat berpikir kritis karena model pembelajaran yang masih menggunakan model konvensional, yaitu menggunakan cara-cara (menghafal dan menerima informasi saja) dengan metode ceramah guru yang lebih aktif dan banyak berbicara di dalam kelas dibandingkan siswa. Guru kurang berinovatif, mengajar tidak terstruktur, mengajar yang penting lepas kewajiban sebagai guru, dan itu bertentangan dengan tuntutan kurikulum 2013 yang menginginkan siswa yang lebih aktif belajar. 
Guru yang mengajar dengan cara-cara lama berdampak pada keaktifan dalam belajar, siswa hanya menerima pelajaran apa adanya tanpa membuat siswa untuk belajar secara aktif. Menurut Yamin (2003:65) diantara keterbatasan metode ceramah ialah: a). Perhatian dan motivasi siswa sulit diukur b). Keberhasilan siswa tidak terukur c). Materi kurang terfokus d). Peran serta siswa dalam pembelajaran rendah dan e). Pembicaraan sering melantur. Selain itu, siswa kurang mampu dalam mengoptimalkan buku dan menerima keterangan dari guru saja, sehingga pengetahuan siswa hanya berkutat pada buku saja. Siswa juga mendapat nilai yang rendah pada saat ulangan harian. Hal senada yang disampaikan dalam penelitian Ilah (2017:1) hasil tersebut menunjukkan bahwa model pembelajaran problem based learning metode inkuiri lebih unggul dalam meningkatkan keterampilan berpikir kritis siswa dibandingkan dengan penggunaan metode ceramah.

Berpikir kritis merupakan keterampilan universal. Kemampuan berpikir jernih dan rasional diperlukan pada pekerjaan apapun, ketika mempelajari bidang ilmu apapun, untuk memecahkan masalah apapun, jadi merupakan aset berharga bagi karir seorang.

Sesuai dengan tuntutan kurikulum terbaru yaitu kurikulum 2013 dan menuju pembelajaran abad 21 dimana dibutuhkan keaktifan siswa serta menggali keterampilan berfikir kritis siswa. Menurut Depdikbud (2017:2) Kecakapan yang dibutuhkan di Abad 21 juga merupakan keterampilan berpikir lebih tinggi Higher Order Thinking Skills (HOTS) yang sangat diperlukan dalam mempersiapkan peserta didik dalam menghadapi tantangan global. Kecakapan yang dibutuhkan antara lain: 1). Kecakapan berpikir kritis dan pemecahan masalah (Critical Thinking and Problem Solving Skill) 2). Kecakapan berkomunikasi (Comminication Skills) 3). Kreatifitas inovasi (Creativity and Innovation) 4). Kolaborasi (Collaboration). Berpikir kritis sangat penting di abad ke 21, karena merupakan era informasi dan teknologi. Seorang harus merespons perubahan dengan cepat dan efektif, sehingga memerlukan keterampilan intelektual yang fleksibel, kemampuan menganalisis informasi, dan mengintegrasikan berbagai sumber pengetahuan untuk memecahkan masalah.

Berdasarkan pree tes di atas sebelum pelaksanaan siklus I sebanyak 36 siswa kelas X.IPS.1 SMA Negeri 9 Tanjung Jabung Timur pada mata pelajaran ekonomi, di dapatkan rata-rata 7,50 dan semuanya di bawah kriteria ketuntasan minimal (KKM) dengan katagori kurang. Oleh karena itu penulis tertarik untuk meniliti Higher Order Thingking Skills (HOTS) dengan model pembelajaran Inquiri.

Menurut penelitian Putri, Yoranda Meinita Dwi, I Wayan Dasna, Oktavia Sulistina, 2014. hal. 36-46) dengan judul "Pengaruh Metode Pembelajaran Inkuiri Terbimbing (Guided Inquiry) untuk Meningkatkan Hasil Belajar dan Kemampuan Berpikir Tingkat Tinggi (Higher Order Thinking Skills) Siswa Kelas X SMA Negeri 1 Malang pada Pokok Bahasan Hidrokarbon". Hasil penelitian ini menunjukkan bahwa terdapat pebedaan hasil belajar kognitif siswa SMA Negeri 1 Malang dimana hasil belajar siswa yang dibelajarkan menggunakan metode pembelajaran inkuiri terbimbing lebih tinggi dibandingkan dengan siswa yang dibelajarkan dengan menggunakan metode konvernsional pada pokok bahasan hidrokarbon. Pembelajaran inkuiri terbimbing tidak hanya meningkatkan hasil belajar kognitif saja, melainkan afektif pula. Pembelajaran inkuiri terbimbing dapat melatih siswa untuk berlatih bersikap ilmiah dalam pembelajaran.

Kemampuan berpikir tingkat tinggi juga menunjukkan bahwa kemampuan berpikir tingkat tinggi siswa yang dibelajarkan dengan metode inkuiri terbimbing lebih tinggi dibandingkan metode konvensional. Kemampuan berpikir siswa dapat dilatihkan melalui kegiatan dimana siswa diberikan suatu masalah dalam hal masalah berbentuk soal tes yang bervariasi.

Hal senada dengan penelitian Sutama, I.N, Putu Arnyana, I.B. Jelantik Swasta (2014) dalam judul Tesis "Pengaruh model pembelajaran inkuiri terhadap keterampilan berpikir kritis dan kinerja ilmiah pada pelajaran Biologi kelas XI IPA SMA Negeri 2 Amlapura". Terdapat perbedaan keterampilan berpikir kritis siswa yang mengikuti model pembelajaran inkuiri dengan siswa yang mengikuti pembelajaran langsung (pembelajaran konvensional).

Berdasarkan penjabaran yang telah dikemukakan cukup berdasar mengingat bahwa pemilihan metode pembelajaran yang kurang tepat akan berpengaruh pada suasana belajar siswa. Model pembelajaran Inkuiri yang diterapkan dalam pembelajaran ini sangatlah tepat dengan keterampilan berpikir kritis siswa, sesuai dengan tingkat ranahnya yaitu ranah berpikir tingkat tinggi diharapkan peserta didik menemukan sendiri jawaban dari masalah yang dihadapinya dalam model pembelajaran tersebut.

\section{METODE PENELITIAN Setting dan Objek Penelitian}

Penelitian tindakan kelas ini difokuskan pada upaya meningkatkan berpikir tingkat tinggi siswa pelajaran ekonomi kelas X IPS.1 melalui model Inquiri di SMAN 9 Tanjung Jabung Timur, tujuannya adalah untuk mengetahui efektifitas atau adanya perubahan dalam model Inquiri dalam upaya meningkatkan keterampilan berpikir tingkat tinggi siswa serta mengetahui seberapa besar peningkatan keterampilan berpikir tingkat tinggi siswa dengan menggunakan model Inquiri. Melalui penggunaan model Inquiri diharapkan siswa mampu meningkatkan keterampilan berpikir tingkat tinggi siswa. Penelitian tindakan kelas ini dilaksanakan pada kelas X.IPS.1 di SMAN 9 Tanjung Jabung Timur pada semester ganjil tahun pembelajaran 2018/2019.

\section{Subjek Penelitian}

Pelaksanaan penelitian tindakan kelas ini bertempat di SMAN 9 Tanjung Jabung Timur pada mata pelajaran ekonomi. Subjek penelitian adalah siswa kelas X IPS. 1 tahun pelajaran 2018/2019 yang berjumlah 36 orang. Dalam penelitian ini, peneliti bertindak sebagai guru. Dalam pelaksanaannya dibantu oleh teman sejawat yaitu Abdul Kasim dan guru ekonomi bertindak sebagai peneliti 


\section{Metode Penelitian}

Penelitian ini menggunakan metode Penelitian Tindakan Kelas (PTK) yaitu suatu pencermatan terhadap kegiatan pembelajaran berupa sebuah tindakan yang disengaja dimunculkan dan terjadi dalam sebuah kelas secara bersamaan (Arikunto, 2006). Langkah-langkah penelitian yang dilakukan melalui tahapan, a). Perencanaan b). Pelaksanaan tindakan c). Observasi d). Refleksi.

\section{Prosedur Penelitian}

Penelitian ini merupakan penelitian tindakan (action research), karena dilakukan untuk memecahkan masalah di kelas. Dalam penelitian ini peneliti menggunakan model yang dikembangkan oleh Kemmis \& Taggart yang meliputi empat tahapan yaitu (1) perencanaan (planning), (2) pelaksanaan (acting) (3) pengamatan (observing), (4) refleksi (reflecting).

Peneliti dalam penelitian tindakan ini bertindak sebagai guru, sedangkan penanggung jawab penuh penelitian ini adalah guru bersangkutan. Tujuan utama dari penelitian tindakan ini adalah untuk meningkatkan keterampilan berpikir tingkat tinggi siswa di kelas, dimana guru secara penuh terlibat dalam penelitian mulai dari perencanaan, tindakan, pengamatan, dan refleksi.

Ada beberapa siklus yang terdapat dalam prosedur penelitian tindakan kelas ini, yaitu apabila siklus I pembelajaran telah selesai dimana telah diketahui beberapa informasi dari hasil analisis data penelitian dan kemudian dilakukan refleksi guna membuat pembelajaran yang lebih baik. Pada siklus berikutnya, perencanaan direvisi dengan memodifikasi dalam bentuk mengurangi pernyataan-pernyataan guru yang bersifat mengontrol siswa, agar strategi bertanya dapat berlangsung dengan baik. Pada tahap tindakan siklus kedua hal itu dilakukan. Pelaksanaannya dicatat dan direkam untuk melihat pengaruhnya terhadap perilaku siswa. Pelaksanaan siklus II untuk memperbaiki beberapa kelemahan pada siklus I sekaligus meningkatkan kualitas pembelajaran. Apabila keterampilan berpikir tingkat tinggi siswa dari siklus I ke siklus II sudah menunjukkan peningkatan, berarti pada penelitian ini cukup dilakukan sampai pada siklus II. Namun jika keterampilan berpikir tingkat tinggi siswa dari siklus I ke siklus II belum menunjukkan peningkatan yang signifikan, maka akan dilakukan refleksi guna membuat pembelajaran yang lebih baik untuk memperbaiki beberapa kelemahan yang terdapat pada siklus I dan siklus II dan penelitian dilanjutkan ke siklus berikutnya yaitu ke siklus III.

\section{Instrumen Penelitian}

Instrumen yang digunakan dalam penelitian ini terdiri dari: 1) Rencana Pelaksanaan Pembelajaran (RPP). 2) Lembar Kerja Peserta Didik (LKPD). 3) Lembar Pengamatan.

\section{Teknik Pengumpulan Data}

Teknik pengumpulan data dalam penelitian ini ialah: 1) Lembar Observasi. 2) Lembar Soal. 3) Wawancara. Teknik ini digunakan untuk menguatkan data-data yang telah ada, karena sebagaimana yang dikatakan oleh Muspawi (2018) bahwa pada prinsipnya pelaksanaan wawancara dimaksudkan untuk mendapatkan data yang cukup sehubungan dengan pokok masalah penelitian yang telah diidentifikasi. 4) Catatan Lapangan. Teknik ini sejenis dengan catatan anekdot, tetapi mencakup kesan dan penafsiran subjektif (Madya, 2011:79). 5) Jurnal (Catatan Harian).

\section{Instrumen Tes HOTS}

Keterampilan berpikir tingkat tinggi merupakan variabel terikat pada penelitian ini, instrument yang digunakan untuk mengukurnya adalah tes, tes dilaksanakan setelah diberikan perlakuan (posttest). Dalam upaya mendapatkan data yang tepat dan akurat, maka tes yang dugunakan dalam penelitian ini harus memenuhi kriteria suatu tes yang baik. Tes yang diberikan untuk mengetahui keterampilan berpikir tingkat tinggi mengenai ekonomi berupa soal-soal pilihan ganda (multiple choice). Soal-soal di buat sendiri oleh peneliti yang disesuaikan dengan Standar Kompetensi (SK), Kompetensi Inti (KI), dan Indikator Pencapaian Kompetensi (IPK) yang terdapat dalam silabus kurikulum 2013 (K-13).

\section{HASIL DAN PEMBAHASAN Hasil Penelitian Siklus I.}

Penelitian siklus I dilaksanakan pada tanggal 30 Juli, 06 Agustus, 13 Agustus 2018 sebagaimana telah dijelaskan pada bab dalam metode penelitian, penelitian pada siklus I dibagi menjadi dalam empat kegiatan yaitu: 1) perencanaan, 2) pemberian tindakan, 3) observasi dan 4) refleksi:

\section{Perencanaan tindakan siklus I}

Tahap perencanaan tindakan pada siklus I meliputi kegiatan yang terdiri dari: 1) Menyusun Rencana Pelaksanaan Pembelajaran (RPP) untuk pertemuan pertama, kedua, dan ketiga. 2) Menetapkan materi bahan ajar siklus I. 3) Menyusun skenario pembelajaran dengan menggunakan model Inquiri. 4) Menyiapkan lembar observasi atau pengamatan untuk melihat bagaimana situasi belajar mengajar di dalam kelas.

\section{Implementasi Tindakan Siklus I}

Pada siklus pertama dan pertemuan pertama, peneliti memulai Penelitian Tindakan Kelas (PTK) untuk melihat bagaimana penggunaan model inquiri oleh guru, agar dapat meningkatkan kemampuan HOTS siswa kelas X SMAN 9 Tanjung Jabung Timur. Indikator yang ingin dicapai pada pertemuan pertama adalah memahami pengertian ilmu ekonomi, mengidentifikasi masalah ekonomi (kelangkaan/scarcity dan kebutuhan yang relatif tidak terbatas) dan memahami konsep pilihan (kebutuhan dan keinginan) dan skala prioritas.

Hasil dari siklus I pertemuan pertama, Kelompok belum memahami benar model pembelajaran lquiri serta langkah-langkahnya, sehingga pada saat pemberian penugasan oleh guru setiap kelompok secara keseluruhan mengalami kesulitan dalam menyelesaikan tugas yang diberikan kepada kelompoknya. Hasil pengamatan dari awal diskusi sampai presentasi siswa kedepan kelas, ternyata ada kelompok yang berhasil menyelesaikan tugas dengan baik yaitu kelompok I, kelompok III, kelompok IV, dan kelompok V. Ada satu kelompok yang tidak dapat menyelesaikan tugasnya dengan baik yaitu kelompok II. Sedangkan satu 
kelompok yang berhasil selesai sesuai dengan langkahlangkah dalam model pembelajaran Inquiri yaitu kelompok I.

\section{Hasil Observasi dan Evaluasi Siklus I}

Hasil observasi gambaran perilaku siswa selama proses pembelajaran berlangsung yang telah diamati oleh teman sejawat sebagai observer dalam penelitian ini, kemudian guru berusaha memberikan stimulus untuk merangsang pertanyaan yang HOTS. Siswa berusaha untuk menjawab pertanyaan-pertanyaan di lembar kerja peserta didik secara individu.

Berdasarkan hasil test Siklus I yang dilakukan tanggal 20 Agustus 2018 maka di dapatkan hasil secara keseluruhan, bahwa ada kenaikan rata-rata hasil ujian yang diperoleh oleh siswa dalam ujian tersebut 30,81 sedangkan pada pre test rata-ratanya adalah 19,65 walaupun belum mencapai rata-rata ketuntasan sebesar 60. Secara garis besar menunjukkan bahwa dengan model pembelajaran Inquiri telah berhasil meningkatkan hasil belajar siswa walaupun masih ada beberapa siswa nilainya tidak stabil karena dalam nilai test tersebut justru nilainya menurun tetapi tidak terlalu mempengaruhi. Sesuai dengan Kriteria Ketuntasan Minimal (KKM) sama dengan 60 dari hasil tes siklus I di atas ternyata tidak satupun siswa yang tuntas sesuai dengan kriteria yang telah ditetapkan. Dalam test tersebut satu orang siswa tidak ikut ujian karena izin. Nilai tertinggi adalah 57 dan nilai terendah dengan nilai di dapatkan siswa ada dua orang anak yaitu atas nama Fran Ario Wardana dan Nalindra Athend Divyanda dan nilai terendah Eka Yulianti dengan nilai 10. Diharapkan nantinya pada siklus II akan ada kenaikan nilai dan perbaikan pembelajaran yang lebih baik lagi dari siklus I.

\section{Hasil analisis dan refleksi siklus I}

Hasil pelaksanaan siklus I menunjukkan bahwa peningkatan hasil belajar siswa dengan menggunakan model inquiri belum sepenuhnya berhasil atau belum terpenuhinya indikator keberhasilan yang telah ditetapkan dalam penelitian. Ketidakberhasilan dapat dilihat dari rendahnya hasil belajar siswa dalam pelaksanaan pembelajaran. Hal ini disebabkan oleh kendala-kendala yang dihadapi peniliti dalam proses pembelajaran.

Kendala-kendala yang peniliti hadapi pada pelaksanaan siklus I adalah: 1) Banyak siswa yang ribut ketika berdiskusi kelompok. 2) Banyak siswa yang mengobrol ketika guru menjelaskan materi pelajaran. 3) Banyak siswa yang belum memahami langkah-langkah dalam diskusi. 4) Banyak siswa yang kurang memperhatikan saat guru menjelaskan tujuan pembelajaran yang harus dicapai. 5) Hanya satu atau dua orang saja yang bekerja dalam kelompok yang lainnya hanya melihat saja dan ngobrol. 6) Hanya berapa siswa saja yang bertanya jika belum memahami tugas dalam diskusi kelompok ketika belum mengerti. 7) Sikap siswa tidak bisa bekerja sama dalam kelompok jika anggota bukan teman akrab. 8) Siswa kurang aktif menanggapi hasil kelompok lain walaupun hanya sekedar memberikan pertanyaan dari perwakilan kelompok

Mengatasi kendala-kendala tersebut peneliti melakukan diskusi dengan teman sejawat untuk memperbaiki rendahnya hasil belajar pada siklus I, dari hasil analisis di atas perlu dilakukan siklus 2, dengan melakukan beberapa perbaikan, yaitu: 1) Mempertahankan langkah-langkah kegiatan yang baik pada siklus I seperti membuat siswa yang tidak ribut disiklus 1 tetapi tidak ribut juga disiklus berikutnya. 2) Membuat siswa lebih aktif secara keseluruhan dan mengurangi hal-hal yang tidak perlu dalam diskusi seperti bercanda. 3) Guru harus lebih jelas dan tegas serta harus lebih riinci lagi dalam menyampaikan tujuan pembelajaran dengan bantuan power point. 4) Membuat siswa lebih fokus dan menikmati diskusi yang lebih menarik dan menyenagkan. 5) Sesuai dengan saran siswa pada siklus I pada sesi wawancara, bahwa guru harus lebih banyak memberikan soal-soal latihan dan pekerjaan rumah (PR).

\section{Hasil Penelitian Siklus II. \\ Perencanaan tindakan siklus II}

Tahap perencanaan tindakan pada siklus II meliputi kegiatan yang terdiri dari: 1) Menyusun Rencana Pelaksanaan Pembelajaran (RPP) untuk pertemuan pertama, kedua, dan ketiga. 2) Menetapkan materi bahan ajar siklus II. 3). Menyusun skenario pembelajaran dengan menggunakan model Inquiri. 4) Menyiapkan lembar observasi atau pengamatan untuk melihat bagaimana situasi belajar mengajar di dalam kelas.

\section{Implementasi Tindakan Siklus II}

Pada siklus kedua dan pertemuan kedua, peneliti memulai Penelitian Tindakan Kelas (PTK) untuk melihat bagaimana penggunaan model inquiri oleh guru, agar dapat meningkatkan kemampuan HOTS siswa kelas $X$ SMAN 9 Tanjung Jabung Timur. Indikator yang ingin dicapai pada pertemuan pertama adalah peserta didik mampu mengidentifikasi masalah pokok ekonomi.

\section{Hasil Observasi dan Evaluasi Siklus II}

Hasil observasi gambaran perilaku siswa selama proses pembelajaran berlangsung yang telah diamati oleh teman sejawat sebagai observer dalam penelitian ini, kemudian guru berusaha memberikan stimulus untuk merangsang pertanyaan yang HOTS. Siswa berusaha untuk menjawab pertanyaan-pertanyaan di lembar kerja peserta didik secara individu.

Setelah pelaksanaan siklus II telah dilaksanakan dengan model Inquiri di dalam kelas, dengan menggunakan langkah-langkah pembelajaran dengan berbagai rekomendasai pada siklus I untuk memperbaiki pembelajaran yang kemudian dapat meningkatnya keterampilan berpikir tingkat tinggi pada siswa. Maka selanjutnya diadakan tes siklus II untuk mengetahui perubahan dari ada tidaknya peningkatan keterampilan berpikir tingkat tinggi (HOTS) pada pembelajaran dengan menngunakan model Inquiri pada mata pelajaran ekonomi khususnya kelas X.IPS.1 SMA Negeri 9 Tanjung Jabung Timur.

\section{Hasil analisis dan refleksi siklus II}

Berdasarkan data dan hasil belajar siswa pada siklus I, dapat disimpulkan bahwa peningkatan hasil belajar siswa dengan menggunakan model inquiri belum sepenuhnya berhasil atau belum terpenuhinya indicator keberhasilan yang telah ditetapkan dalam penelitian. 
Ketidakberhasilan dapat dilihat dari rendahnya hasil belajar siswa dalam pelaksanaan pembelajaran. Hal ini disebabkan oleh kendala-kendala yang dihadapi peniliti dalam proses pembelajaran.

Adapun kendala-kendala yang dihadapi peniliti pada pelaksanaan kegiatan pembelajaran pada siklus II berdasarkan hasil peniliti dan teman sejawat adalah: 1) Masih ada siswa yang ribut ketika berdiskusi kelompok. 2) Hanya satu atau dua orang saja yang bekerja dalam kelompok yang lainnya hanya melihat saja dan ngobrol. 3) Siswa kurang aktif menanggapi hasil kelompok lain walaupun hanya sekedar memberikan pertanyaan dari perwakilan kelompok

Mengatasi kendala-kendala tersebut dilakukan diskusi dengan teman sejawat untuk memperbaiki rendahnya hasil belajar pada siklus I, dari hasil analisis di atas perlu dilakukan siklus 3, dengan melakukan beberapa perbaikan, yaitu sebagai berikut: 1) Membuat siswa lebih fokus dan menikmati diskusi yang lebih menarik dan menyenangkan. 2) Sesuai dengan saran siswa pada siklus II pada sesi wawancara, bahwa guru harus lebih banyak memberikan soal-soal latihan dan pekerjaan rumah (PR). 3) Atas saran di wawancara siswa untuk memberikan soal-soal pilihan ganda pada akhir siklus, kemudian memberikan kisi-kisi soal sebelum pelaksanaan test akhir ujian. 4) Memperbanyak media dalam pembelajaran, termasuk media gambar, atau media karton yang membuat siswa lebih tertarik dalam pembelajaran. 5) Sebelum pelaksanaan tes, terlebih dahulu guru memberikan kisi-kisi soal kepada siswa.

\section{Hasil Penelitian Siklus III \\ Perencanaan tindakan siklus III}

Tahap perencanaan tindakan pada siklus III meliputi kegiatan yang terdiri dari: 1) Menyusun Rencana Pelaksanaan Pembelajaran (RPP) untuk pertemuan pertama, kedua, dan ketiga. 2) Menetapkan materi bahan ajar siklus III. 3). Menyusun skenario pembelajaran dengan menggunakan model Inquiri. 4) Menyiapkan lembar observasi atau pengamatan untuk melihat bagaimana situasi belajar mengajar di dalam kelas.

\section{Implementasi Tindakan Siklus III}

Pada siklus ketiga dan pertemuan pertama, peneliti memulai Penelitian Tindakan Kelas (PTK) untuk melihat bagaimana penggunaan model inquiri oleh guru, agar dapat meningkatkan kemampuan HOTS siswa kelas X SMAN 9 Tanjung Jabung Timur. Indikator yang ingin dicapai pada pertemuan pertama adalah peserta didik mampu menjelaskan konsep produksi (Pengertian produksi, faktor-faktor produksi, teori perilaku produsen, konsep biaya produksi, konsep penerimaan, dan laba maksimum).

\section{Hasil Observasi dan Evaluasi Siklus III}

Hasil observasi gambaran perilaku siswa selama proses pembelajaran berlangsung yang telah diamati oleh teman sejawat sebagai observer dalam penelitian ini, kemudian guru berusaha memberikan stimulus untuk merangsang pertanyaan yang HOTS. Siswa berusaha untuk menjawab pertanyaan-pertanyaan di lembar kerja peserta didik secara individu.

\section{Pembahasan}

Berdasarkan hasil pengamatan siswa dari siklus 1 , Siklus II, dan siklus 3, bahwa kegiatan observasi sikap siswa dilakukan dalam kelas untuk melihat perkembangan berpikir tingkat tinggi siswa. Dari 5 kegiatan yang dilakukan oleh guru di dalam kelas, terjadi peningkatan berpikir tingkat tinggi bagi siswa. Pada observasi/pengamatan pada siklus I siswa yang aktif ada 12 siswa, kemudian pada siklus II suda mulai mengalami perubahan dalam belajar sebesar 30 siswa yang aktif dalam belajar. Dan pada siklus III semua siswa telah aktif dalam belajar. Pada sesi wawancara pada siklus I ada 5 siswa yang berhasil diwawancarai, kemudian pada siklus II ada 3 siswa yang diwawancarai secara acak, dan pada siklus III semua siswa diwawancarai secara bersama dalam belajar tentang kesulitan-kesulitan soal dan pembelajaran dalam kelas. Pada Catatan lapangan dilakukan pada pertemuan pertama siklus I nampak siswa masih banyak bingung dan ribut dalam diskusi kelompok serta keaktifan yang masih kurang, sedangkan pada siklus II sudah mulai terlihat keaktifan dalam belajar maupun dalam mengerjakan tugas LKPD. Dan pada siklus III siswa sudah lebih akatif dan menyatu dalam belajar dengan model pembelajaran Inquiri. Catatan harian dilakulkan setiap pertemuan pada masing-masing siklus untuk melihat atau merekam kejadian-kejadian di dalam kelas, baik kejadian yang sifatnya perilaku positif siswa maupun kejadian perilaku anak yang bersifat negatif selama pembelajaran berlangsung.

Tabel 1. Penilaian Diskusi Kelompok Siklus 1, Siklus II, dan Siklus III

\begin{tabular}{clcccc}
\hline No & Variabel yang diamati & Siklus I & Siklus II & Siklus III \\
\hline 1 & $\begin{array}{l}\text { Jumlah siswa dalam } \\
\text { belajar }\end{array}$ & 36 & 36 & 36 \\
2 & $\begin{array}{l}\text { Jumlah siswa yang } \\
\text { tuntas }\end{array}$ & 35 & 36 & 36 \\
3 & $\begin{array}{l}\text { Persentase ketuntasan } \\
\text { siswa } \\
\text { Jumlah siswa yang tidak } \\
\text { tuntas }\end{array}$ & 1 & 0 & $100 \%$ \\
\hline
\end{tabular}

Berdasarkan tabel 4.28 Keaktifan siswa dalam diskusi kelompok dari siklus I 97,22\% dengan jumlah siswa sebanyak 36 orang dan1 siswa yang belum mencapai standar KKM dan yang tuntas sebanyak 35 orang. Kemudian pada sisklus II mengalami peningkatan keaktifan dalam diskusi kelompok siswa yang telah mencapai KKM sebesar $100 \%$. pada siklus III semua siswa telah mencapai standar KKM atau sebesar $100 \%$.

Hasil penelitian ini sejalam dengan penelitian yang dilakukan oleh Annafi (2017) yang membuktikan bahwa terjadi peningkatan Higher Order Thinking siswa melalui model pembelajaran Inkuiri pada mata pelajaran IPA kelas V SD N Triharjo. Hasil penelitiannya menunjukkan bahwa peningkatan nilai rata-rata siswa diperoleh hasil rata-rata nilai siswa pra siklus yaitu 64,92 , pada siklus I nilai rata-rata siswa mencapai 67,39 dan pada sklus II rata-rata nilai siswa mencapai 76,15 . Pada pra siklus ke siklus I mengalami peningkatan 2,46 dan pada siklus I ke siklus II mengalami peningkatan 8,76. Siswa yang telah mencapai KKM atau tuntas belajar pada pra siklus 
sebesar 30,76\% atau terdapat 8 siswa dari 26 siswa yang telah mencapai KKM. Sedangkan 67,38\% atau terdapat 16 siswa yang belum tuntas belajar. Persentase ketuntasan pada pra siklus I termasuk dalam katagori "sangat kurang". Persentase ketuntasan belajar siswa pada siklus I mencapai $46,16 \%$ atau terdapat 14 siswa dari 26 siswa yang telah mencapai KKM. Persentase ketuntasan pada pra siklus I termasuk dalam katagori "cukup baik". Hasil persentase ketuntasan belajar pada silus II mencapai $80,76 \%$ atau terdapat 21 siswa dari 26 siswa yang telah mencapai KKM. Sedangkan 19,24\% atau terdapat 5 siswa yang belum tuntas belajar. Persentase ketuntasan pada siklus II termasuk dalam katori "sangat baik". Berdasarkan hasil penelitian yang dilakukan diperoleh peningkatan pada pra siklus, siklus I, dan siklus II. Persentase ketuntasan belajar mengalami peningkatan pra siklus ke siklus I mencapai 20,08\% dan pada siklus I ke siklus II mengalami peningkatan $26,92 \%$.

Hasil penelitian ini juga sesuai dengan penelitian yang dilakukan oleh Prayitno, dkk, 2013) dengan judul "Penerapan Integrasi Sintaks Inkuiri dan STAD (INSTAD) untuk Meningkatkan Kemampuan Berpikir Tingkat Tinggi Siswa Kelas VII-D SMPN 27 Surakarta". Yang mana setelah siswa belajar dengan menggunakan model pembelajaran INSTAD kemampuan berpikir tingkat tinggi mengalami kenaikan dari siklus I ke siklus II.

Kuantitas dan kualitas pertanyaan siswa selama pembelajaran dan hasil tes berpikir tingkat tinggi siswa dari siklus I ke siklus II mengalami peningkatan. Kenaikan skor dari siklus I ke siklus II sebesar 7,08 untuk aspek rerata berpikir tingkat tinggi dan sebesar 16,19 untuk aspek ketuntasan klasikal. Peningkatan kemampuan berpikir tingkat tinggi dalam penelitian ini juga menunjukkan perubahan positif dalam pembelajaran. Penerapan model pembelajaran INSTAD dapat mengurangi dominasi guru dalam pembelajaran.

Hasil penelitian sesuai juga dengan penelitian yang dilakukan oleh Kurnianigsih, dkk, (2013) dengan judul "Perbedaan kemampuan Berpikir Tingkat Tinggi dan Pemahaman Konsep Materi Hidrolis Garam Siswa MA Negeri 2 Malang pada Penerapan Model Pembelajaran Inkuiri Terbimbing". Hasil penelitiannya menunjukkan bahwa: 1) Pembelajaran inkuiri berjalan dengan baik yang ditunjukkan dengan terjadinya peningkatan prosentase keterlaksanaan pembelajaran dari $63 \%$ menjadi $91 \%$. 2) Ada percobaan persentase tingkat kemampuan berpikir tingkat tinggi antara kelas XI IPA 2 (58,38\%). 3) Ada percobaan persentase tingkat pemahaman konsep siswa kelas IPA 3 (740) dan XI IPA $2(65 \%)$.

Menurut Shoimin (2014:85) Model pembelajaran Inkuiri adalah rangkaian kegiatan pembelajaran yang menekankan pada keaktifan siswa untuk memiliki pengalaman belajar dalam menemukan konsep-konsep materi berdasarkan masalah yang diajukan.

Inkuiri adalah suatu model pembelajaran yang berpusat pada siswa di mana kelompok siswa Inkuiri ke dalam suatu isu atau mencari jawaban-jawaban terhadap isi pertanyaan melalui suatu prosedur yang digaris secara jelas dan struktural kelompok" (Kourilsky dalam Hamalik, 2001:220). Pembelajaran ini tidak membiarkan siswa untuk menunggu jawaban dari guru, melainkan mencari sendiri pemecahan dari masalah, sehingga siswa lebih dapat termotivasi dan tidak terpusat pada satu pernyataan saja dalam mencari pemecahan masalah.

Pembelajaran Inkuiri mendorong siswa untuk belajar sebagian besar melalui keterlibatan aktif mereka sendiri untuk dapat melakukan percobaan dan memiliki pengalamannya sendiri sehingga dimungkinkan mereka menemukan prinsip dan konsepnya sendiri sesuai arahan guru (Nurhadi dan Senduk, 2003:7).

Model pembelajaran Inkuiri merangsang siswa untuk dapat belajar sendiri, mencari sendiri, mencurahkan seluruh pengalaman dan kemampuan intelektualnya untuk menganalisis materi pelajaran yang disajikan sehingga kemampuan siswa dalam belajar dapat tumbuh kembang secara optimal sesuai dengan kemampuan mereka masing-masing.

Berdasarkan pendapat para ahli tersebut dapat penulis kemukakan bahwa model pembelajaran inquiri adalah model pembelajaran yang berpusat pada siswa yang menekankan pada keaktifan siswa dalam pembelajaran, serta dapat merangsang siswa untuk dapat belajar, mencari sendiri, dan menemukan konsepkonsep tertentu serta memecahkan sendiri persoalan yang dihadapinya dalam pembelajaran.

Menurut Roestiyah (2008:20) keunggulan model pembelajaran Inkuiri ialah: 1). Membantu dalam menggunakan ingatan. 2) Dapat mengembangkan konsep diri pada diri siswa. 3) Mendorong siswa untuk dapat berpikir dan bekerja atas inisisatif sendiri. 4) Memberi kepuasan intrinsik. 5) Mendorong siswa untuk berpikir intuitif. 6) Situasi proses belajar mengajar dapat lebih terangsang. 7) Memberi kebebasan siswa untuk belajar sendiri. 8) Dapat mengembangkan bakat. 9) Dapat menghindari cara-cara belajar tradisional. 10) Dapat memberikan waktu siswa untuk dapat mengakomodasikan dan mengasimilasi konfirmasi. Sedangkan kelemahannya ialah: 1) Metode ini sulit dalam merencanakan pembelajaran oleh karena terbentur dengan kebiasaan siswa belajar. 2) Jika metode pembelajaran Inkuiri digunakan sebagai metode pembelajaran, maka akan sulit mengontrol kegiatan dan keberhasilan siswa. 3) Selama kriteria keberhasilan belajar ditentukan oleh kemampuan siswa menguasai materi pelajaran, maka metode pembelajaran inkuiri akan sulit diimplementasikan oleh setiap guru. 4) Kadang-kadang dalam mengimplementasikannya memerlukan waktu yang panjang sehingga sering guru sulit menyesuaikannya dengan waktu yang telah ditentukan.

\section{SIMPULAN}

Berdasarkan penelitian yang telah penulis lakukan dapat disimpulkan bahwa penerapan Model Pembelajaran Inquiri dapat meningkatkan Higher Order Thinking Skils dalam pelajaran Ekonomi pada siswa kelas X.IPS.1 SMA N 9 Tanjung Jabung Timur. Hal tersebut dapat diketahui rata-rata kenaikan dan kelulusan dari siklus ke siklus. Pada siklus I persentase kelulusan belajar siswa sebesar $36,11 \%$ dan soal HOTS 
sebanyak 13 buah, dan pada siklus II mengalami peningkatan sebesar $41,67 \%$ dengan soal HOTS sebanyak 15 buah.

\section{DAFTAR PUSTAKA}

Annafi, Fina Sari Nur, Wahyu Kurniawati, 2017. Meningkatkan Higher Order Thinking iswa melalui Model Pembelajaran Inquiri pada Mata Pelajaran IPA: Yogyakarta. Jurnal PGSD Indonesia.Volume 3. Nomor 3.

Arikunto, Suharsimi. 2006. Penelitian Tindakan Kelas. Jakarta: Bumi Aksara.

Depdikbud, 2017. Implementasi Pengembangan Kecakapan Model Abad 21 dalam RPP: Jakarta. Direktorat Pendidikan SMA.

Hamalik, Omar. 2001. Proses Melajar Mengajar. Jakarta: Bumi Aksara.

Kurnianingsih Ragil, Srini M. Iskandar, Dermawan Afandy, 2013 Perbedaan Kemampuan Berpikir Tingkat Tinggi dan Pemahaman Konsep Materi Hidrolisis Garam Siswa MA Negeri 2 Malang pada Penerapan Terbimbing, Universitas Negeri Malang.

Ilah, 2017. Pengaruh Model Pembelajaran Problem Based Learning (PBL) Metode Inquiri terhadap Keterampilan Berpikir Kritis Siswa (Studi Eksprimen pada Mata Pelajaran Ekonomi di SMA Negeri 1 Ciamis). Jurnal Wahana Pendidikan. Universitas Galuh.

Madya, Suwarsih, 2011. Penelitian Tindakan (Action Research) Teori dan Praktik Bandung: Alfabeta.

Muspawi, Mohamad. 2018. Implementasi Prosedur Kerja Pengawas PAl Sekolah Dasar di Kabupaten Sarolangun. Jurnal IImiah Universitas Batanghari Jambi Vol.18 No.3 Tahun 2018. Hal. 580-588.

Prayitno, Baskoro Adi, Bowo Sugiharto, Wahyu (2013). Penerapan Integrasi Sintaks Inkuiri dan STAD (INSTAD) untuk meningkatkan kemampuan Berpikir Tingkat Tinggi Siswa Kelas VII-D SMPN 27 Surakarta. Jurnal Bioedukasi. Vol.6 No.1. Hal.34-38.

Putri, Yoranda Meinita Dewi, I Wayan Dasna, Oktavia Sulistina, 2014. Pengaruh Metode Pembelajaran Inkuiri Terbimbing (Guided Inquiry) untuk Meningkatkan Hasil Belajar dan Kemampuan Berpikir Tingkat Tinggi (Higher Order Thinking Skill) Siswa Kelas X SMA Negeri 1 Malang pada Pokok Bahasan Hidrokarbon. Jurnal Universitas Negeri Malang.

Roestiyah, N.K (2008). Strategi Belajar Mengajar. Jakarta: Rinekacipta.

Shoimin, Aris, 2014. 68 Model Pembelajaran Inovatif. Yogyakarta: Ar-Ruzz Media.

Sutarma, I Nyoman, Ida Bagus Putu Arnyana, Ida Bagus Jalentik Swasta, 2014. Pengaruh Model Pembelajaran Inkuiri Terhadap Keterampilan Berpikir Kritis dan Kinerja IImiah pada Pelajaran Biologi Kelas XI IPA SMA Negeri 2 Amlapura. Pascasarjana, Universitas Pendidikan Ganesha.

Yamin, Martinis. 2003. Strategi Pembelajaran Berbasis Kompetensi. Jakarta: Referensi Gp Press Group. 